\title{
SOCIAL RESILIENCE OF MINORITY GROUP: STUDY ON SHIA REFUGEES IN SIDOARJO AND AHMADIYYA REFUGEES IN MATARAM ${ }^{1}$
}

\author{
Cahyo Pamungkas \\ Lembaga Ilmu Pengetahuan Indonesia \\ Email:cahyopamungkas_lipi@yahoo.com
}

\begin{abstract}
This research conceptually aims to find out the strategy the Shia community in Sidoarjo, East Java, and Ahmadiyya community in Mataram, West Nusa Tenggara, have employed to defend themselves from the pressure of the state and Sunni Muslim as majority group due to the differences in textual interpretation toward Islamic Holy Scriptures (The Qur'an). The theoretical implication from this study is to evaluate and criticize social resilience concept which refers to developmentalistic perspectives such as the use of social capital. In this article, social resilience is closely related to strategy of minorities to establish a tolerant multi religious community. This study argues that social resilience of religious minority groups, i.e. Shia in Sidoarjo and Ahmadiyya in Mataram, is formed by various aspects, such as the government policies on religious life, history of group formation, social relations and network, understanding towards religious values and spirituality, and cultural bonds in the community.
\end{abstract}

Key words: religion, social resilience, refugees, religious minority, and community strategy.

DOI: http:// dx.doi.org/10.20414/ujis.v19i2.418

${ }^{1}$ This article is a revised version of the author's LIPI research monograph (2015) entitled "Social Resilience of Religious Minority Group: A Study on Shia refugees in Sidoarjo and Ahmadiyya refugees in Mataram. 


\section{Introduction}

SOCIAL resilience in the social sciences is often defined as the ability of a community to cope with the pressure and interference from outside the community caused by social, political, and environmental changes. ${ }^{2}$ This study assumes that the ability of Shia refugees in Sidoarjo, East Java, and Ahmadiyya refugees in Mataram, West Nusa Tenggara, to survive is a process which has been growing and developing during the evacuation. Based on the observations, both communities seem to have different level of resilience. The community of Shia refugees relatively gets more attention from government and non-governmental organizations due to their accessible location. However, this makes them more dependent on assistance from others. The background of the refugees, who had previously worked in the subsistence agricultural sector, makes them somewhat difficult to adapt to the refugee camp, i.e. Puspa Agro complex which is closed and located in the area of capital-intensive industry.

This is in contrast to Ahmadiyya refugees in Transito dormitory, Mataram. The location is relatively more open than Puspa Agro complex. They can easily go out and interact with people outside the community. The refugees are aided by their family in the city of Mataram due to the same ethnic background or affiliation. In addition, the refugees can freely work in the informal sector as mentioned. In fact, they are able to give donations to the other refugees to fulfill their daily needs. Although the aids from the government and non-governmental organizations are relatively limited but they are considered to be more independent than Shia refugees in Sidoarjo. However, this explanation contradicts to a study conducted by Nadia Farabi. Farabi found that the resilience of refugee communities in both locations is basically not different. The aid provided by the government to Shia refugee is relatively limited, so it is not

${ }^{2}$ W. Neil Adger, "Social and Ecological Resilience. Are They Related?," Progress in Human Geography 24, no. 3 (2000): 347-364. 
enough to meet their tertiary needs. ${ }^{3}$ Therefore, some of the refugees work in the informal sector such as laundry workers or motorcycle drivers. However, their chances to do those professions are very limited due to the restriction to enter and leave the refugee complex.

The term minority refers to the social groups which are few in number and do not have significant political influence. Social resilience in this study refers to the social resistance possessed by religious minorities who are marginalized in the realm of religion, i.e. Shia community in Sidoarjo and Ahmadiyya community in Mataram. As a result of different interpretation on Islamic Holy Scriptures (The Qur'an) with majority Muslim, the two communities are forced to leave their villages and live in the refugee camps. Various studies on the two communities have been carried out by Budiwanti, Burhani, and Mudzakkir. However, they are not focused on the dimensions of social resilience. ${ }^{4}$ Thus, this study tries to fill literature gaps on religious minorities study in Indonesia. This study attempts to look at maintaining the social resilience of religious minorities through efforts to fulfill their civil rights as citizens and to build a tolerant relationship between religious groups. General question to be answered in this article is that what strategy used by Shia refugees in Sidoarjo and Ahmadiyya refugees in Mataram to survive in the refugee camps?

${ }^{3}$ Nadia Farabi, "Hambatan Pemulangan Pengungsi Internal Syia Sampang dan Ahmadiyah Lombok," (Master thesis, Program Pascasarjana Fakultas Ilmu Sosial dan Politik, Universitas Gadjah Mada, Yogyakarta, 2011), 56.

${ }^{4}$ See Erni Budiwanti, "Jama'ah Ahmadiyah and The Indonesian Ulama Edicts," Strategic Review 1, no. 2 (2011): 36-43; "Jemaat Ahmadiyah dan Resistensi Sosial di Lombok," Jurnal Harmoni 4, no. 23, (July-September: 2007): 36-61; "Pluralism Collapses: A Study on the Jama'ah Ahmadiyah Indonesia and Its Persecution," Working Paper Series No. 117 (National University Singapore: Asia Research Institute, 2009). See also Ahmad Najib Burhani, "Conversion to the Ahmadiyya in Indonesia: Winning Hearts through Ethical and Spiritual Appeals," Sojourn: Journal of Social Issues in Southeast Asia (ISEAS), 29, no.3 (Nov 2014): 657-690. See also Amin Mudzakkir, "Minoritisasi Ahmadiyah di Indonesia," Masyarakat Indonesia 37, no. 2 (2011): 1-25; "Menjadi Minoritas di Tengah Perubahan: Dinamika Komunitas Ahmadiyah di Ciparay," in Hak Minoritas, Multikulturalisme, dan Dilema Negara Bangsa ed. Mashudi Noorsalim, M. Nurkhiron, Ridwan al-Makassary (Jakarta: Interseksi, 2007), 195-235. 


\section{The Factors that Establish Social Resilience}

Studies of human ecology interpret social resilience as the competence of a community, i.e. the ability of the community to cope with all the problems that disrupt both from inside (internal conflicts) or outside by using its available resources. ${ }^{5}$ This definition is able to explain why the oppressed minority groups are capable of living and reproducing cultural identity. The other researchers of human ecology explain that the ability of a community to survive is closely related to the ability to undertake collective action which influenced by human interaction, the organization's resources, and social capital in the community to improve the welfare of community. ${ }^{6}$ The ability of these communities can be differentiated in terms of its dimensions in relation to the sustainability of the social system, which is seen as an ecological, i.e. the capacity to overcome the challenges that arise from outside the community, the capacity to learn past experiences and adjust them to meet the challenges in the future, and the capacity to establish institutes which improve the welfare of its members and sustainable social forces both in the present and the future. ${ }^{7}$ Thus, ecologically, factors that establish social resilience are network structure and social relations, power and institutional relations, and knowledge and discourse. Social capital as the most important factor in shaping social resilience is a major concern because of its role in

\footnotetext{
${ }^{5}$ Christopher C. Sonn, dan Adrian T. Fisher, "Sense of Community: Community Resilient Responses to Oppression and Change," Journal of Community Psychology, 26 (1998): 457-472.

${ }^{6}$ See Kristen Magis, "Community Resilience: An Indicator of Social Sustainability," Society \& Natural Resources 23, no. 5 (2010): 401-416. See also John McKnight dan John Kretzmann, Building Communities from the Inside out: A Path Toward Finding and Mobilizing A Community's Assets (Evanston, IL: Center for Urban Affairs and Policy Research, Neighborhood Innovations Network, Northwestern University, 1993); Stephen B. Fawcett et al., "Using Empowerment Theory in Collaborative Partnerships for Community Health and Development," American Journal of Community Psycholgy 23, no. 5 (1995): 677-697.

${ }^{7}$ Markus Keck and Patrick Sakdapolrak, "What is Social Resilience? Lessons Learned and Ways Forward," Erdkunde 67, no. 1 (2013): 5-19.
} 
addressing social vulnerability and capability in generating economic, cultural, and symbolic capital. ${ }^{8}$

It is different to the approach of human ecology, cultural approach emphasizes that social resilience is formed by the association of individual with family and community which closely related to the construction of cultural identity and transformation of spiritual values including religion. ${ }^{9}$ The transformation of value can be seen in the form of oral tradition, storytelling, humor stories, traditional rituals, and religious rituals. These aspects support the transmission of cultural knowledge. Cultural perspective in shaping social resilience is also explained by Gunnestad who stated that social resilience is formed by the following three factors. ${ }^{10}$ First is network factor, i.e. external support including family, relatives, friends, co-workers, neighbors, members of the organization. Second is the ability and expertise which cover the resources. Third is the meaning, value, and trust as support to keep existing. Cultural values can be viewed by members of the community as a signpost. As a consequence, if a person can internalize the trusted value in the community then these values will be a hint to avoid problems and a guide to live together in happiness.

Religion, containing the dimension of values, can give someone hope because they believe in the existence of God whom can be communicated with through worship. On the

8Joseph S. Mayunga, "Understanding and Applying the Concept of Community Disaster Resilience: A Capital-based Approach," Working Paper for the Summer Academy for Social Vulnerability and Resilience Building (Munich: Summer Academy for Social Vulnerability and Resilience Building, 2007), 1-16. See also Brigit Obrist, Constanze Pfeiffer, and Robert Henley, "Multi-Layered Social Resilience: A New Approach in Mitigation Research," Progress in Development Studies 10, no. 4 (2010): 283-293 and W. Neil Adger, "Social and Ecological Resilience: Are They Related?," Progress in Human Geography 24, no. 3, (2000): 347-364.

'Laurence J. Kirmayer et al., "Community Resilience: Models, Metaphors and Measures," Journal of Aboriginal Health 5, Issue 1 (November 2009): 62-117.

${ }^{10}$ Arve Gunnestad, "Resilience - A New Approach to Children at Risk in the Southern African Situation," in Children's Rights in Early Childhood Education in Africa and Norway ed. Arve Gunnestad (Trondheim: Network for Preschool Teacher Training and Preschool Development in Southern Africa, 2003), 45-59; "Resilience in a Cross-Cultural Perspective: How Resilience is Generated in Different Cultures," Journal of Intercultural Communication issue 11 (2006): 1-29. 
other hand, engagement with the community and religion are often seen as part of forming social resilience. If this phenomenon is seen from the perspective of social resilience, basically both refugee communities are very vulnerable or can be said to have no ability to survive socially and economically. However, in the perspective of theology, members of the two communities are still able to maintain their theological beliefs. Religion in the eye of Durkheim is one of the instruments to maintain social integration through the main practice of rituals. ${ }^{11}$ In this context, the social resilience is determined by social fact such as cultural and religion values.

Based on the approach of action theory introduced by Bourdieu, social praxis conducted by community is manifestation of the formation of social resilience. The main concept of Bourdieu's action theory will be used to analyze the issue of social resilience, i.e. strategy, trajectory (history), and babitus. ${ }^{12}$ Social resilience in this study will be seen from the strategy of community to gain recognition from other social groups. In this case, it is assumed that refugee community has struggle with other social groups in a particular domain. The relation of Shia and Ahmadiyya community with other groups will be seen from the trajectory, the historical development of these two communities. The use of habitus to examine religious communities has been conducted by Saba Mahmood who explains resignation phenomena invested in the community. ${ }^{13}$ Resignation based on the belief that Ahmadiyya will follow the way of prophet Isa, through suffering, is one of the strengths possessed by Ahmadiyya community to survive until today. ${ }^{14}$

In the following section, the concept of habitus will be explained according to Bourdieu along with other related

${ }^{11}$ Emile Durkheim, The Elementary Forms of the Religious Life (New York: The Free Press, 1965), 62.

12Pierre Bourdieu, Outline of $A$ Theory of Practice, translated by Richard Nice (Cambridge: Cambridge University Press, 1997), 78.

${ }^{13}$ Saba Mahmood, Politics of Piety: The Islamic Revival and the Feminist Subject (Princeton and Oxford: Princeton University Press, 2005), 26.

${ }^{14}$ Ahmad Najib Burhani, "When Muslims are not Muslims: The Ahmadiyya Community and the Discourse on Heresy in Indonesia," (Ph.D. diss., University of California, Santa Barbara, 2013), 360-363. 
concepts. Habitus has two dimensions, i.e. subjective structure which is externalized and objective structure internalized into a social actor. ${ }^{15}$ Both objective and subjective structure are used to determine perception, attitude and praxis of the social actors. Habitus is often seen as a depiction of a series of tendencies that encourage a person to act and react in certain ways; generate praxis, perception, and regular behavior; and create valid habit. ${ }^{16}$ Tendencies have habitus emerged through implantation, systematic, everlasting, developing, and removable.

Relating to power relation, this study expands the idea of the importance of state intervention to restore the condition of the two communities in order they do not have disadvantages socially. The government is considered to do less effort in returning them to their home areas. In fact, the government is subject to the pressure of the majority group. The pressure is in the form of criteria to be fulfilled by the refugees, i.e. returning to Islamic belief possessed by majority (Sunni Muslims). In this context, the definition of social resilience which only emphasize on community capacity is not enough if it is viewed from citizenship aspect. Thus, in the context of developing countries, social resilience cannot be just conceptually understood as autonomy and capacity of the community but also it includes the importance of the state's active role to protect minority groups so that they have strength to keep growing and developing.

Based on a number of prior studies regarding social resilience and empirical conditions of Ahmadiyya refugee, the factors that establish social resilience are as follows: (i) The ability of a community to survive ecologically can be seen in the level of its autonomy. This is seen from the ability to meet basic needs; (ii) Social resilience is shaped by social capital and network structure possessed by the community in which they are used to sustain the community life; (iii) the social resilience of a community is also closely related to power and institutional relation. Factors that will be seen is the active role of the state in the form of intervened policy to protect the citizenship's right of

15Pierre Bourdieu, Language and Symbolic Power translated by Gino Raymond and Matthew Adamson (Cambridge: Harvard University Press, 1991), 12.

16Ibid. 
members of the minority group; (iv) Social resilience of minority group is formed by the elements of culture and spirituality including religious belief. (v) Social resilience of a community is social praxis which closely link to its history and tradition formed in the past.

\section{National Context of Shia Refugee in Sidoarjo and Ahmadiyya in Mataram}

Refugees are social group categorized as the most vulnerable groups in the world since they left their hometown, all possessions and livelihoods. They also have no assurance of life in new place. According to the convention of UNHCR 1951 "refugee is a person -due to well-founded fear of persecution caused by some reasons such as race, religion, nationality, membership of a particular social group and membership of a particular political party- who stays outside the country of his nationality and do not want protection from the state". ${ }^{17}$ Based on the definition of UNHCR, refugee in this study can be categorized as internal refugee, i.e. a person or a particular social group who unwillingly leaves his homeland for fear of violence action committed by the majority group. Thus, refugees can be categorized into refugees caused by different political views and refugees caused by differences in religious views. The difference is the latter category of refugees in general has difficulty or they even cannot return to their hometown.

In May 2012, in its report to the Human Rights Council, the Indonesian government actually has reaffirmed its commitment to protect minorities, freedom of religion, and promised to solve the problems of intolerance. This statement is ironic because in fact Ahmadiyya refugees in Mataram and Shia in Sidoarjo remained in limbo without any certainty and legal guarantee from the central to the local government regarding how long the evacuation take place. The approach from state in handling the refugees can be divided into two, i.e. security approach which considers the refugees as a threat to the government and human approach which refers to the fulfillment of basic rights of

${ }^{17}$ UNHCR, Convention and Protocol Relating to the Status of Refugees (Geneva: Communication and Public Communication Service, 2010), 14. 
individuals. ${ }^{18}$ However, in handling Shia refugee in Sidoarjo and Ahmadiyya in Mataram, beyond both approaches, the state has done ambivalence. On one side, government is committed to solving the problems of refugees. And on the other side, both communities are left away. This condition, using the concept of Agamben, can be called as the act of exclusion by the state to maintain social and political stability in both regions. ${ }^{19}$

Violence and intimidation against these communities seem to have theological justification when Council of Indonesia Ulama (Majelis Ulama Indonesia/MUI) at national and local level issued deviance statement (fatwa). Opposition action against Ahmadiyya in national level emerges after the 1998 reform, with the issue of MUI statement as a result of the $7^{\text {th }}$ MUI National Consensus on July 26 $6^{\text {th }}-29^{\text {th }} 2005$. The content of statements (fatwa) are: (i) reaffirmed the statement (fatwa) of MUI in 1980 that Ahmadiyya is deviant and misleading, (ii) members of Ahmadiyya sect should return to the teachings of Islam, and (iii) government is obliged to ban the dissemination of Ahmadiyya teachings around Indonesia and dismiss its organization. Likewise, the decision of MUI regional East Java No. Kep-01 / SKF-MUI / JTM / I / 2012 agree on the decision of local MUI in East Java which states that Shia, especially Imamiya Itsna Asyariya or who uses the pseudonym mad₹hab ablul bait, is misguided and misleading. MUI regional East Java recommends Muslims to be vigilant in order not to be easily influenced by the ideology and teachings of Shia. However, MUI also asked Muslims to not be easily provoked to do violence against Shia group.

The statement of MUI as mentioned above has implication in term of the pressure on the sustainability of the lives of religious minority groups labeled as a misleading sect. This not only gives negative impact on social resilience of refugee community at the micro level in which their future as citizens are in uncertainty, whether or not they will return home. It also

${ }^{18}$ Atik Krustiyati, "Kebijakan PenangananPengungsi di Indonesia: Kajian dari Konvensi Pengungsi tahun 1951 dan Protokol 1967," Law Review 12, no. 2 (November 2012): 185-186.

${ }^{19}$ Giorgio Agamben, Homo Sacer: Sovereign Power and Bare Life (California: Stanford University Press, 1998), 81. 
indirectly influences the future of social resilience in the society, nation and the state especially in case of a guarantee for diversity. ${ }^{20}$ Freedom of religion and worship in accordance with their own belief become questionable when those are different to religious belief by majority group. Religious life will be a monolithic and interpretation space of religious texts will become homogeneous. Differences in the interpretation of religious texts will not get a room and tend to ignore the act of violence against the minority groups. Religious minority groups should have religious and cultural recognition that they are part of Indonesia in which their citizenship rights are protected.

The relationship between the majority Sunni Muslim and religious minority sects in Islam is also related to discourse contestation and interest groups at the international, national, and local level. Formichi mentions that the spread of Syia teachings in Indonesia, for example, is associated with interest toward the success of Islamic revolution in Iran in 1979. ${ }^{21}$ The discourse of anti-Shia in Indonesia is thus a series of government's worries in New Order era regarding the spirit of Iranian revolution (1983-1984), reaction to temporary marriages (1995), fall of New Order regime was followed by a struggle of power (1997), and the impact of increasing influence of MUI in the context of religious orthodoxy. Before reform era, opposition against Shia is merely religious discourse. The acts of violence against Shia began in 2000, followed in the period of 2006 and 2013. In addition to the voices of anti-Ahmadiyya, the increasing dichotomy on Sunni and Shia can be seen as reaction to the fall of Islam from power as a result of presidential winning for Megawati in 2001. This phenomenon, along with the increasing role of MUI, contributes to a higher number of violent conflicts between religious groups. According to Klinken and Sidel, polarization of Maluku and Poso conflict at the end of 1999 occurred when Islamic politic lost its power in Jakarta which led to the loss of patronage network at the local.

\footnotetext{
${ }^{20}$ Syafiq Hasyim, "Majelis Ulama Indonesia and Pluralism in Indonesia," Philosophy \& Social Criticism 41, no. 4-5 (2015): 487-495.

${ }^{21}$ Chiara Formichi, "Violence, Sectarianism, and the Politics of Religion: Articulations of Anti- Shi'a Discourses in Indonesia," Indonesia, no. 98 (October 2014): 1-27.
} 


\section{The Condition of Refugees and Survival Strategy}

The violence against Ahmadiyya community in Lombok began in 1999 when a group of unidentified persons attacked and set fire to a resident's house which also functioned as a mosque in Bayan, North Lombok. In 2004, a group of persons set fire to the settlement of Ahmadiyya community in Pancor, East Lombok. The members of Ahmadiyya who are willing to return to the teachings of Sunni Islam are allowed to stay in Pancor. Otherwise, they will be forced to leave East Lombok. Then, in 2005, attacks on Ahmadiyya community occurred again in the settlement of Ahmadiyya community in BTN BumiAsri, Ketapang, Lingsar, West Lombok. As a result, 36 families were evacuated in Transito dormitory until now. In 2006, Ahmadiyya in Central Lombok were attacked and their homes were burned so that they were evacuated in the former General Hospital Praya, Lombok.

Since 2006, most of the Ahmadiyya communities from North Lombok, East Lombok and West Lombok have become refugees in Transito dormitory, Mataram. They were overwhelmed by the uncertainty of their future whether they will be relocated or settled permanently in the dorm. A part of them have stayed out of the dormitory and settled in Mataram. Most of those who still live in dormitory worked as farmers or in their old work place. Some of them have livelihood in Mataram regional market as grocers, seller of vegetables, coconuts cutter, motorcycle drivers, market porters, and others. With limited or even the absence of government aids, the refugees have to work hard to survive. They were able to establish a saving and credit union managed by community members who work as traders and give a charity every month. Their social resilience can be quite good economically, in terms of their degree of autonomy are high enough so that they can fight for hard and uncertain condition in the refugee camps.

Shia community in Sampang was forced to leave their home town to seek refuge in Puspo Agro dormitory, Sidoarjo in 2012. At that time, their settlement was attacked and burned by Sunni Muslim community a week after the celebration of 'T $d$ al-Fitr. Some literature state that the problems began in 1983 when one of the charismatic 
Muslim scholars in Sampang, Kyai Ma'mun, who was interested in the success of Iranian revolution in 1979, sent their children(Iklil, Tajul Muluk, Roisul Hukama, and Ummi Hani) to study at Yayasan Pesantren Islam(YAPI) Bangil, a Shia Jafariyah sect. ${ }^{22}$ The action was opposed by his brother, a great Muslim scholar in Madura, Ali Karrar, from family of Batu Ampar. Kyai Karrar has a strong network to Badan Silaturahmi Ulama Pesantren Madura (Meeting Board of Muslim Scholars from Islamic Schools in Madura) and Forum Musyawarah Ulama Pamekasan (The Muslim Scholars Board in Pamekasan). YAPI is considered misleading because they apply the teachings of Shia and have no affiliation with the Islamic schools that have been established in the land of Madura.

In 1999, Tajul Muluk returned home from studying religion in Saudi Arabia. In 2004, he started introducing Shia teachings to public in Sampang. Tensions begin to emerge between Tajul Muluk with Muslim scholars in Bluruan and Karanggayam villages, Omben district. Tajul successfully established Misbahul Huda Islamic School which was warmly welcomed by local people. Kyai Karrar once again expressed his opposition toTajul Muluk for spreading the ideology of Shia. However, it did not make conflict because the Muslim scholars still respect Kyai Ma'mun. Tajul Muluk and Rois Hukana implement different ways of worship. They often help rural communities in economic aspect, assist communities in handling public administration, radically change the ritual of prophet Muhammad birthday called maulidan (old ritual is from house to house, then it is centralized in the mosque) and hold night guard in the village.

Then conflicts emerged between Tajul Muluk and his brother Roisul Hukaa due to marital problems of Tajul Muluk's student. As a consequence, Roisul Hukana returned to Sunni teachings and had hostile on Tajul Muluk and his community. This led to violence action against Shia community in Sampang.

${ }^{22}$ Ali Humaedi, "Kerusuhan Sampang: Kontestasi Aliran Keagamaan dalam Wajah Kebudayaan Madura", Harmoni 13, no. 2, (Mei-Agustus 2014): 147; Muhammad Afdillah, "Dari Masjid ke Panggung Politik: Studi Kasus Peran Pemuka Agama dan Politisi dalam Konflik Kekerasan Agama antar Komunitas Sunni dah Syia di Sampang Jawa Timur," (thesis, Sekolah Pascasarjana Program Studi Agama dan Lintas Budaya, Universitas Gajah Mada, Yogyakarta, 2013); Kontras Surabaya, Laporan Investigasi dan Pemantauan Kasus Shia Sampang (Surabaya: Kontras, 2012). 
Actually, we cannot reduce the conflict of Shia as rooted in the conflict between the two brothers. However, it is more precise to lay on the phenomenon of scour on properly established power and economic structures, controlled by a local Muslim scholar and thugs. Since the existence of Tajul, the income of Islamic scholars was reduced because the ritual of maulidan was centrally held in the mosque. Likewise, with the night guard, theft was reduced so that the revenue of thugs was decreased. The issue was becoming bigger when Tajul said that all Muslim scholars in Madura were envelope-oriented scholars. The issue was not clarified then it became wild ball. Hereinafter Muslim Scholars Board in Madura, MUI, and PCNU (Branch Structure of NU) in Sampang issued official statement that Shia teachings followed by Yajul Muluk were misguided and misleading. The conflicts which initially covered Karanggayam and Bluruan village then it spread to the rest of Sampang.

Unlike Ahmadiyya refugees in Transito dormitory, Shia refugees in Sidoarjo receive monthly subsidies from local government. However, the presence of tip (JADUP) and various facilities in dormitory raised a dilemma, i.e. on the one hand, it increases the welfare of refugees. On the other hand, it changes their life style and consumption. The welfare is temporary, but it is often not realized. This makes their durability in the evacuation more dependent on the help of the local government. Findings indicate that some refugees are also working in the informal sector to earn additional income as satay sellers, barber, coconut cutting labors, and others. They also make deposit book to save money so that they will not spend the money for consumption only.

This finding supports studies of social resilience in human ecology as used by Sonn and Fisher, Adger et al., Magis, and Kretzmann and McKnight. ${ }^{23}$ In the perspective of human ecology, the community of Shia refugee in Sidoarjo and Ahmadiyya refugee in Mataram can be said to have sufficient ability to use internal resources, such as credit unions and employment in the informal sector, to cope with economic

\footnotetext{
${ }^{23}$ See again Sonn and Fisher, "Sense of Community" (1988), Adger et al., "Social Ecological" (2005), Magis, "Community Resilience" (2010) and Kretzmann et al., Building (1993).
} 
pressures. Likewise, the differences and internal conflicts within the community are always solved by discussion led by community leaders. For example, when Shia community will be relocated to Sampang for one requirement, i.e. return to Sunni teachings, it was rejected by the refugee community through group discussion. Such kind of ecological perspective analogizes the people as animal community which in general can survive the pressures of natural and internal conflicts. Although they are able to explain how to survive physically for life, but such approach does not have the future in the social sciences because of the inability to explain the complexities of society, not only to survive physically but also able to maintain their theological belief.

\section{Social Relation and Network of Refugees}

Social relation of refugees can be seen in conjunction with the main community organization which has guided and protect them. Shia refugees have international and national networks such as Ahlul Bait Indonesia (ABI). Tajul Muluk was the leader of Ikatan Jamaah Ahlul Bait Indonesia (IJABI, the association of Shia Community in Indonesia) in Sampang. But after having got out from the jail, Tajul had closer ties with ABI. This organization advocates three basic rights of Shia refugee: the right to the fulfillment of basic needs of refugees, the right to access education and freedom of worship, and the right to obtain security guarantees from all forms of intimidation and discrimination. The close relationship between Shia refugees and ABI was not caused by the organization, but the reason is the popularity of Tajul Muluk among refugees. However, ABI regional East Java actively monitors the condition of refugees and provides advocacy to refugees who are facing legal issues such as negotiating with the government.

Meanwhile, the social relation of Ahamdiyya refugee with Jemaah Ahmadiyya (Ahmadiyya community organization) is stronger than the relationship of Shia community with ABI. Unlike Syia community, close relationship of Ahmadiyya refugee with Ahmadiyya international community is due to organizational relationship. As explained earlier, every social 
activity conducted by Ahmadiyya refugee is always supported and guided by Jamaah Ahmadiyya Indonesia (JAI, Ahmadiyya member's organization in Indonesia). JAI is basically an extension of spiritual power of Ahmadiyya's caliph domiciled in London. The structure of JAI consists of leadership board at province, county, district, and community. Ahmadiyya's preachers who accompany the community received training for several years in India or Pakistan. JAI has a very important role in determining propaganda and mission of Ahmadiyya at the local level. The system of Ahmadiyya Caliphate makes consultations and effective control mechanisms to the community level.

The field findings show that Shia and Ahmadiyya refugees have strong relationship with religious organization at the local, national, and international level. Structurally, both refugee communities are component of those organizations. In each preach on Friday, regional preachers always convey the messages of Ahmadiyya caliphate in London. Likewise, Shia community is always getting spiritual direction and guidance from Ahlul Bait Indonesia (ABI) through regular recitals. Legal advocacy is also provided by ABI when the leader of Shia community in Sampang brought to justice. The same thing was done by the regional preachers that seek to represent the community when dealing with the government. However, both communities do not have relation with the power nationally and locally. This is indicated by their weak position in facing Sunni group. They are also incapable of creating a discourse in public room. This makes them powerless in mass media.

Field data shows that social capital within members of the refugee community can be seen in the form of mutual trust and external network to non-government institutions and colleges. The mutual trust establishes high level of solidarity among refugees so that they help each other in everyday life such as lending money, saving money in credits union, and the tradition of mutual cooperation. Network with non-governmental institutions can be utilized to obtain trainings or advocacy for their citizenship rights. In this case, a good relationship with some progressive scholars makes their aspirations raised in public spaces in local and national level. 
The findings of this study reinforce previous studies which describe the use of social capital in establishing social resilience, for example Mayun Ga and Obrist, et al. ${ }^{24}$ They emphasize the importance of having capital bya community as a factor of social resilience. Capital can be in the form of economic capital, physical capital, natural capital, and human capital. Sakdapolrak only focuses on the importance of social capital that produces those other capitals. Social capital is recognized as a key factor that plays a role in building and maintaining social resilience. However, the approach of social capital is not enough to answer the question why they survive until now in refugee camps. The ecological approach is only able to explain some of the social and power relations which influence the resilience of Shia and Ahmadiyya refugees.

\section{The Role of State and a Possible Reconciliation}

Power relation in this study was associated with the political sphere occupied by the local government and local political groups such as tuan guru (Muslim who has wide knowledge on Islam and important role in community) in Lombok or kyai and thugs in Madura. Apparently, the refugee communities do not have enough political capital in the realm of local politics. Until now, they have no political forces at the local level which support the process of reconciliation for refugees.

Field research shows that East Java and West Nusa Tenggara (NTB) Provincial Government have different way of responding the problem of refugees. East Java Provincial Government played an active role in caring for refugees such as allocating budgets, transferring refugees from GOR (Sport Arena) in Sampang to dormitory in Sidoarjo, providing financial aids, ensuring the security of refugees, healing the refugees who have psychological pressure, and minimizing further conflict. The management of refugees in dormitory is handled by Regional Disaster Management Agency (BPBD) which opens office in dormitory. This is in contrast with the policy of NTB provincial government which seemed to ignore the refugees in Transito dormitory and only provide aids during the first three months. NTB provincial administration is basically a

${ }^{24}$ MayunGa, “Understanding” (2007), OBrist et al., “Multi-Laeyered” (2010). 
government supported by Nahdlatul Wathan (NW), the largest Islamic community in NTB. Some members of NW are the main actors in attacking Ahmadiyya community. In case of making identification card (KTP), the provincial government does not provide any assistance because the status of Ahmadiyya community is still refugees. However, Majeluk sub-district government provides ID card service because they are considered as residents in the sub-district. This is due to the intensive cultural approach conducted by Lakspesdam NU (one of the Islamic communities in Indonesia) toward sub-district administration, refugees, and people around Transito dormitory. Both provincial governments (NTB and East Java) do not have a road map for reconciliation between refugees and perpetrators and relocation of the refugees to their homeland.

Regarding the possibilities of reconciliation between there fugees and communities around, Shia and Ahmadiyya community are considered deviant and misleading by Majelis Ulama Indonesia (MUI, Indonesian Islamic Scholars Council). This status might have formed a perspective for most people and some government officials. As a result, most of the government's policies toward Shia and Ahmadiyya community are helpless. In each process of reconciliation initiated by the government and MUI in East Java or in NTB, Shia and Ahmadiyya community are required to repent so that they can return to their home town. The state regulation on religious life (UUNo.PNPS1/1965on prevention, abuse, and desecration of religion) states that the government has right to manage religious life in order to create conduciveness. In fact, this kind of regulation can be one of the discrimination instruments toward religious minority groups.

Refugees in Indonesia are mostly categorized as internal refugee. Thus, the government has full right to manage them. In this context, the international organizations and global communities do not have authority to intervene. Comparing to trans-national refugees, internal refugees stay at their own country and have complete documents. However, they are treated by the government and people as illegal citizens. Transito and Puspo Agro dormitory for certain reasons can be considered as quarantine or shelter for the refugees to feel save for a while. They were not allowed to return home but also they are prohibited to settle in that place forever. 
In the context of creating reconciliation, some Muslim communities in Indonesia are the silent majority. They consider that the violence against religious minorities such as Shia and Ahmadiyya should be avoided. Meanwhile, the government tends to be passive and its decision is influenced by active groups which support religious intolerance and violence. Reconciliation processes in both refugee communities have been carried out by local government. For example, West Lombok government has a reconstruction program for Ahmadiyya community. But in reality, this program cannot be run and Ahmadiyya community remains in the refugee camps. The obstacle is the obligation for Ahmadiyya to repent (return to Sunni teachings). According to the refugees, the best reconciliation is to make Transito dormitory as their home forever so that they are treated equally as other residents.

Moderate religious leaders and intellectuals in Mataram organized dialogues to respond the violence against Ahmadiyya. However, dialogues are not effective way to stop the violence against Ahmadiyya. Another effort is pioneered by Lakspesdam $\mathrm{NU}$ in the form of social reconciliation program namely social inclusion. This program engages refugees in activities with the community around Transito dormitory. Lakspesdam indirectly provide learning to the local community that Ahmadiyya community is not an exclusive group. It is also to remind Ahmadiyya community so that they should refrain from their mission to spread the ideology of Ahmadiyya to local community. This is different from the process of reconciliation in Surabaya. President Susilo Bambang Yudoyono (SBY) and governor Soekarwo asked rector of UIN (Islamic State University) Sunan Ampel Surabaya Abdul A'la to form Shia reconciliation team in Sampang. However, this team did not have clear authority. They just provide recommendations and those recommendations were never considered by the parties.

The contribution of finding of this study is to criticize Agamben's perspective on homo sacer used to analyze Ahmadiyya community as done by Najib Burhani. ${ }^{25}$ Political exclusion in citizenship stems from the concept of homo sacer, i.e. a group of people who are not allowed to be killed, but the person who killed them will not be charged for

25Burhani, "When Muslim” (2013). 
murder. In other words, the position of homo sacer (human which is sacrificed) is between the inside and outside of the state law. They were in the practice of negative exceptions where the rights inherent in citizenship identity are not recognized by the state. According to Burhani, Ahamdiyah is homo sacer since the sacred concept homo sacer means that Ahmadiyya is lawful blood, Ahmadiyya status is between Muslims and non-Muslims, right as Muslim are suspended, and there are evictions and persecution as the consequences of their ambiguous position. $^{26}$

The use of Agamben's concept explains that there is missing line in the political function which changes society from uncivilized condition into humanity. The existence of homo sacer fills this empty space. ${ }^{27}$ However, Agamben's view is not relevant if it is used to analyze social resilience because it does not offer clear solutions, but to reflect on the anthropological concept of human existence in politics. In reality, democracy process which has been running enables negotiation processes between perpetrators and victims of violence. If it is explored further, the refugee community and Sunni Muslim communities who settled around at the micro level utilize the potential to encourage reconciliation processes culturally. This space can be used to strengthen the resilience of society as a whole, i.e. through the cultural approach in the form of informal dialogues.

\section{The Maintenance of Theological Belief and Cultural Bond in Refugee Camps}

Although they live in a refugee camp, Ahmadiyya community can maintain their faith properly. The community members regularly have worship together in a special place using as the mosque. Every Friday, Ahmadiyya members who live around the city of Mataram do Friday prayer with their refugees colleagues in Transito dormitory. The preacher on Friday prayer is regional preacher. He reads the text of preach written by Jamaah Ahmadiyya of London, England. At night, they watch directly Ahmadiyya Muslim Television (MTA) broadcasted by their great leader from London. The Ahmadiyya members living in refugee camps also carry out regular meetings at

${ }^{26}$ Amin Mudzakkir, "Kewarganegaraan dan Kemungkinan Rekonsiliasi Kultural," Research Report LIPI (Jakarta: LIPI, 2015), 113.

${ }^{27}$ Ibid. 
the regional, national, and international level to manage their organization and resolve arising issues.

Thus, Transito dormitory for the Ahmadiyya refugees is not just a place to survive, as described in the concept of social resilience in the perspective of human ecology. Transito dormitory is the center of life and social resilience in social, economic, political, and culture of Ahmadiyya commnity in Mataram. Transito is a room and media to foster solidarity in the organization, inside and outside consolidation and maintain their theological belief that today suffering is something that should be experienced with resignation as a way to spread the teachings of Ahmadiyya to the whole world. Transito is the center of Ahmadiyya movement in which members of the community share their experiences and also reproduce imagination about a better future.

Unlike Ahmadiyya refugees in Mataram, Shia refugees in Sidoarjo use the same mosque with Sunni community in dormitory. Nevertheless, Shia preachers from Ahlul Bait Indonesia regional East Java province regularly provide religious lectures to refugees. Ustadz Iklil, chairman of refugee community, often provide religious guidance formally and informally. Observations show that the factors establishing social resilience for Shia refugees are not only shaped by theological beliefs but also tribal bonds, i.e. very strong sense of Madura. As evidence, the refugees in Sidoarjo also maintain relationship with their neighbors or relatives in Sampangin by means of receiving family visits. However, they are still barred from returning to their hometown. This is what makes Shia refugees feel deprived of its cultural roots.

One of the important findings in this study is that social resilience of Shia and Ahmadiyya refugees are formed by the theological beliefs, especially Karbala doctrine and resignation theology for Ahmadiyya. Najib Burhani in his dissertation mentioned that one of the strengths of Ahmadiyya community is a theological belief that all the repressions and the pressures they have are a test for them to recognize the levels of faith. ${ }^{28}$ What has been experienced by Mirza Ghulam Ahmad was also experienced by Jesus Christ when spreading Christianity. The relation between prophet Isa and prophet Musa is analogous to

${ }^{28}$ Burhani, “When Muslim”, (2013). 
the relation between Mirza Ghulam Ahmad and Prophet Muhammad. Thus, Ahmadiyya community believes that submission to Allah in the suffering in this world will be rewarded with the widely dissemination of Ahmadiyya teachings throughout the world. This theological conviction was believed by the Ahmadiyya community members, including those who live in evacuation. The Ahmadiyya refugees in Mataram regarded Transito dormitory as the center of worship to defend the teachings of Ahmadiyya and spread them around.

The same thing relates to the doctrine of Karbala, belief in the teachings of Shia, that the suffering they have is a form of sacrifice as practiced by Imām 'Ali and Imām Hussein. Shia followers must not give up to the misery. Otherwise, they should make all forms of suffering in the world as a passion for welcoming Imam Mahdi. He is believed to freeing the entire human race from oppression. As with Ahmadiyya refugees, Karbala doctrine is instilled through the activities of religious teaching so that the refugee will be center of the movement and the teaching of Shia. Such a doctrine is considered to motivate then to survive in refugee camps. The approach of social fact, Durkhemian is only able to explain the function of religious rituals on the strengthening of community solidarity, but it has not been able to offer an approach to analyze social resilience in the long term. Moreover, such an approach denies the role of the agencies and individuals inside the community which conduct negotiations for reconciliation processes.

The use of Bourdieu's concept to describe Shia religious traditions is conducted by Saba Mahmood, as mentioned in terms of religious habitus. Religious habitus is a set of tendencies, rooted in a particular religious tradition embedded and reproduced continuously, which encourages individuals to think, do the statements and act in certain ways. Habitus can be seen in the practices of religious rituals and social practices as well. For example, the tradition of Asyura commemoration in Syia community is understood as media to commemorate the sacrifice of Imām 'Ali. In this context, the habits in religious traditions both Shia and Ahmadiyya play a role in shaping social and religious praxis. It is also the strategy to gain recognition as a religious minority group. 
These findings reinforce previous studies which link social resilience and culture as conducted by Kirmayer, et al. and Gunnestad. Kirmayer's study, for instance, finds that social resilience consists of spiritual and cultural elements such as the transmission of cultural knowledge, religious rituals, and knowledge of the culture that links people with history. The importance of values, meaning and trust as social resilience factors are also described by Gunnestad. According to him, external supports (including family, relatives, friends, coworkers, neighbors, members of the organization), the capability and expertise possessed by the community members, and the values and beliefs are the capital for a society to exist when dealing with external pressure. It is said that the cultural values can be viewed by members of the community as a signpost so that they can be motivated to survive. As a consequence, if a person can internalize trusted values in the community then these values will be the strength to endure at the individual and community level.

Cultural dimension in social view is reinforced by the role of religious values in establishing social resilience. Individuals' bonds to religious communities can be seen as the determining factors of the social resilience of a community. Religion in the view of Durkheim is one of the instruments to maintain social integration through the main practice of rituals. In this context, social resilience is determined by social facts such as cultural and religious values. One of the findings in this study indicates that in a theological perspective, the members of the two communities are able to maintain their theological beliefs until now. This evidence can be seen from the rejection of both communities towards advises from regional MUI to repent. They chose to remain in camps and live in uncertainty than to repent and return as a Sunni Muslim.

\section{Conclusion}

Based on the above explanations, it can be known that social resilience of Shia community in Sidoarjo and Ahmadiyya community in Mataram is formed by state policy towards minority group, the historical development of the group, networking and social relations, the understanding of the values of religion and spirituality, and cultural bonds to community. However, the historical development of 
the group in the area of origin has not been explored further. Thus, it cannot be clearly found its role in shaping the social resilience. Despite the information on this case is obtained from literature study, but it cannot be discussed comprehensively its links to social resilience.

The policy of NTB provincial government strengthens social resistance amongst the Ahmadiyya. This is in contrast with the policy of East Java provincial government which provides life assurance. On the one hand, this aids support refugees in meeting basic needs. On the other hand, it reduces the level of autonomy and resilience. Social relations with their central organizations and civil organizations play a role in the formation of resilience of communities. For example, Ahmadiyya refugees are able to reach autonomy in managing their life in camps and have good relations with local residents. The understanding of theological beliefs encourages the strengthening of the capacity of refugee communities to survive for both Ahmadiyya and Shia. There is no doubt that Karbala doctrine and resignation theology are instrumental in building self-confidence and motivation for these communities. Meanwhile, cultural linkages with the community are something inherent in the creation of strong solidarity in refugee camps. It also plays a significant role in the formation of social resilience as theological beliefs do. It seems that social resilience of Shia refugees in Sidoarjo is shaped stronger by cultural bonds, i.e. bond as Madura tribe.

Social resilience in this study can be identified from the ability of the refugees to address the problem of basic needs fulfillment and get appropriate job, the protection from local communities, and the rights of citizenship. Social resilience is not something comes from the outside, but it has lived and rooted in the community. For example, awareness and desire to survive collectively based on either religious affiliation or tribal bonds. It is not something comes from outside or something given or provided by other parties. Outside parties such as local government, central religious organizations (JAI and $A B I)$, civil organization, and campus only provide the ideas and initiatives which facilitate the community to find ways to overcome their problems in the refugee camps, adapt to the environment, and transform all sufferings into strength to develop in the long term. 
Using Bourdieu's perspective, we can say that social resilience of Ahmadiyya and Shia refugees is something that grows, develops, and is reproduced continuously in recent years. The capacity to stand and overcome the problems in the refugee camps is formed through their suffering experiences, collective memory of violence, its discriminative and marginalized position in religious, or in other words their position as homo sacer. However, the capacity is also shaped by cultural and religious traditions invested in the past. The resilience of community at the individual level is also born from the ability of community leaders to negotiate their interests with the surrounding community. Dialectic between structure and agency is a continuous social process which strengthens the autonomy and social resilience of the refugees.

Social resilience in the context of this study is a community strategy to gain recognition of their religious beliefs as a recognized sect in Islam. Thus, social resistance has exceeded the strategy to survive physically in terms of socio-economic. It is also recognition of their rights as citizens and recognition of their belief which is accused of heresy and misleading. Social resilience as a strategy to deal with two kinds of power, i.e. First, the power which gave birth to intimidation, terror and persecution. Second, symbolic power. That is the power which gives unfeeling violence. Symbolic power can be seen from the authority of Muslim scholars especially MUI which states that Ahmadiyya and Shia cult.

Although Bourdieu's concepts can be used to analyze the issue of social resilience of Ahmadiyya and Shia refugees in Indonesia but there are a number of theoretical problems. For example, there are no clear boundaries between religious habitus and social practices existed in the reality of everyday life. It is also overlapping between the religious and the political sphere, which sphere influences other sphere. Sphere is not something autonomous in the religious domain. The statement of MUI, which labels Ahmadiyya in Mataram or Shia in Sampang as misleading group, has link tothe relations of political forecast the local level such as Nahdlatul Wathan and Nahdlatul Ulama scholars with political parties. In this case, the use of dominance relation concept in the sphere is in fact not appropriate because in addition to dominance relation in the practice of everyday life, there are also peaceful relations between the parties involved in conflict. 
Based on the findings, this study gives three recommendations three things. First, further research on the possibilities of reconciliation is needed at the grassroots level, i.e. between refugees with community in their hometown although though the spaces for reconciliation seem to have already closed because of different interpretations on the teachings of Shia and Ahmadiyya. However, there is still a chance for some elements in Sunni Muslim groups and the parties in the government who want the refugees return to their hometown. If the refugees cannot return, relocation should be attempted with the involvement of refugees and communities in the area where they will settle, in order to avoid the recurrence of violence against Ahmadiyya and Shia.

Second, the central government especially the Ministry of Home Affairs and the Ministry of Religious Affairs in cooperation with East Java and West Nusa Tenggara provincial government should actively facilitate the process of reconciliation among the refugees with community in the area of origin with regard to the principles of citizenship, i.e. the protection to all citizens of Indonesia. The government should be above all religious groups and ensure there is no discrimination against citizens based on ethnic and religion. In other words, the government must act decisively to repatriate these refugees to their home by promoting consensus and reconciliation. It should be main concern of government since the resilience in the life of a nation in the future will be fragile when the country is organized to fulfill the interests of majority without regarding to justice for all citizens.

Third, Islamic community organizations such as PWNU in East Java, PCNU in Sampang, Central Board of NW should promote cultural approach in dealing with refugees. Ahmadiyya refugees are fellows seeing from cultural perspective as Lombok ethnic. It is also same with Shia refugees who still have close ties with culture of Madura tribe. The differences in the interpretation of the teachings of Islam should not break ethnic bonds and brotherhood that has been built over the years. Social resilience of Muslims will be stronger when differences in the interpretation of Islam are solved through discussion and consensus. It does not use violence and political pressure either. Wa al-Lāh a làm bi al-sawāb. 


\section{References}

Adger, W. Neil. "Social and Ecological Resilience: are They Related?," Progress in Human Geography 24, no. 3 (2000): 347-364. Adger, W. Neil., T. Hughes, C. Folke, S. R. Carpenter, and J. Rockström. "Social-Ecological Resilience to Coastal Disasters." Science 309 (2005): 1036-1039.

Afdillah, Muhammad. "Dari Masjid ke Panggung Politik: Studi Kasus

Peran Pemuka Agama dan Politisi dalam Konflik Kekerasan Agama antar Komunitas Sunni dah Syia di Sampang Jawa Timur." Master thesis, on Sekolah Pascasarjana Program Studi Agama dan Lintas Budaya, Universitas Gajah Mada, Yogyakarta, 2013.

Agamben, Giorgio. Homo Sacer: Sovereign Power and Bare Life. California: Stanford University Press, 1998.

Bourdieu, Pierre. Outline of A Theory of Practice, translated by Richard Nice. Cambridge: Cambridge University Press, 1977.

--------. The Logic of Practice, translated by Richard Nice. Stanford, California: Stanford University Press, 1990.

---------. Language and Symbolic Power. The $5^{\text {th }}$ Edition, edited by John B. Thompson and translated by Gino Raymond and Matthew Adamson. Cambridge: Harvard University Press, 1991.

Bourdeu, Pierre and Loic J. D. Wacquant. An Invitation to Reflexive Sociology. Chicago: University of Chichago Press, 1992.

Budiwanti, Erni. "Jama'ah Ahmadiyya and the Indonesian Ulema Edicts." Strategic Review 1, no. 2 (2011): 36-43.

------. "Jemaat Ahmadiyya dan Resistensi Sosial di Lombok." Harmoni 6, no. 23 (Juli-September 2007): 36-61.

"Pluralism Collapses: A Study on the Jama'ahAhmadiyya Indonesia and Its Persecution." Working Paper Series. No. 117. National University Singapore: Asia Research Institute, 2009.

Burhani, A. Najib. "When Muslims are not Muslims: The Ahmadiyya Community and the Discourse on Heresy in Indonesia." Ph.D. diss. University of California, Santa Barbara, 2013.

. "Conversion to the Ahmadiyya in Indonesia: Winning Hearts through Ethical and Spiritual Appeals." Sojourn 29, no. 3 (November 2014): 57-690.

"Treating Minorities with Fatwas: A Study of the Ahmadiyya Community in Indonesia." Contemporary Islam 8, no. 3 (September 2014): 285-301. 
Durkheim, Emile. The Elementary Forms of the Religious Life. New York: The Free Press, 1965.

Farabi, Nadia. "Hambatan Pemulangan Pengungsi Internal Syia Sampang dan Ahmadiyya Lombok." Master thesis Program Pascasarjana Fakultas Ilmu Sosial dan Politik, Universitas Gadjah Mada, Yogyakarta, 2014.

Fawcett, Stephen B., Adrienne Paine-Andrews, Vincent T. Francisco, Jerry A. Schultz, Kimber P. Richter, Rhonda K. Lewis, Ella L. Williams. "Using Empowerment Theory in Collaborative Partnerships for Community Health and Development." American Journal of Community Psychology 23, no. 5 (1995): 677-697.

Formichi, Chiara. "Violence, Sectarianism, and the Politics of Religion: Articulations of Anti-Shi'a Discourses in Indonesia." Indonesia 98 (October 2014): 1-27.

Gunnestad, Arve. "Resilience - a New Approach to Children at Risk in the Southern African Situation". In Children's Rights in Early Childhood Education in Africa and Norway. Edited by A. Gunnestad, 45-59. Trondheim: Network for Preschool Teacher Training and Preschool Development in Southern Africa, 2003.

"Resilience in a Cross-Cultural Perspective: How Resilience is generated in Different Cultures." Journal of Intercultural Communication 11, (2006): 1-29.

Hasyim, Sya fiq. "MajelisUlama Indonesia and pluralism in Indonesia." Philosophy \& Social Criticism 41, no.4-5 (2015): 487-495.

Humaedi, Ali. "Kerusuhan Sampang: Kontestasi Aliran Keagamaan dalam Wajah Kebudayaan Madura." Harmoni 13, no. 2 (May August 2014): 117-133.

Keck, Markus, and Patrick Sakdapolrak. "What is Social Resilience? Lessons Learned and Ways Forward." Erdkunde 67, no. 1 (2013): $5-19$.

Kirmayer, Laurence J. MeghaSehdev, Rob Whitley, Stéphane F. Dandeneau, Colette Isaac. "Community Resilience: Models, Metaphors and Measures." Journal of Aboriginal Health (November 2009): 62-117.

Kontras Surabaya. Laporan Investigasi dan Pemantauan Kasus Syia Sampang. Surabaya: Kontras, 2012.

Krustiyati, Atik. "Kebijakan Penanganan Pengungsi di Indonesia: Kajian dari Konvensi Pengungsi tahun 1951 dan Protokol 1967." Law Review 12, no. 2 (November 2012): 171-192.

Mayunga, Joseph S. "Understanding and Applying the Concept of Community Disaster Resilience: a Capital-based Approach.” 22- 
28 Working Paper. Munich: Summer Academy for Social Vulnerability and Resilience Building, Munich, (July 2007): 1-16. Magis, Kristen. "Community Resilience: An Indicator of Social Sustainability." Society \& Natural Resources 23, no. 5 (2010): 401 416.

Mahmood, Saba. Politics of Piety: The Islamic Revival and the Feminist Subject. Princeton and Oxford: Princeton University Press, 2005.

McKnight, John, and John Kretzmann. Building Communities from the Inside out: A Path toward Finding and Mobilizing a Community's Assets. Evanston, IL: Center for Urban Affairs and Policy Research, Northwestern University, 1993.

Mignone, Javier, and John O'Neil. "Social Capital and Youth Suicide Risk Factors in First Nations communities." Canadian Journal of Public Health 96 (Jan-Feb 2005): S51-4.

Mudzakkir, Amin. "Minoritisasi Ahmadiyya di Indonesia." Masyarakat Indonesia 37, no. 2, (2011): 1- 25.

"Menjadi Minoritas di Tengah Perubahan: Dinamika Komunitas Ahmadiyya di Ciparay." In Hak Minoritas, Multikulturalisme, dan Dilema Negara Bangsa. Edited by Mashudi Noorsalim, M. Nurkhiron, Ridwan al-Makassary, 195-235. Jakarta: Interseksi, 2007).

. "Limbo Kewarganegaraan dan Kemungkinan Rekonsiliasi Kultural." In Ketahanan Sosial Kelompok Minoritas Agama: Studi Pengungsi dan Relokasi Komunitas Ahmadiyya di Mataram dan Komunitas Syia di Sidoarjo, edited by Cahyo Pamungkas, 113-130. Jakarta: LIPI, 2015.

Obrist, Brigit, Constanze Pfeiffer, and Robert Henley. "Multi-Layered Social Resilience: A New Approach in Mitigation Research." Progress in Development Studies 10, no. 4 (2010): 283-293.

Sonn, Christopher C., and Adrian T. Fisher. "Sense of Community: Community Resilient Responses to Oppression and Change." Journal of Community Psychology 26, (1998): 457-472.

UNHCR. Convention and Protocol Relating to the Status of Refugees. Geneva: Communication and Public Communication Service, 2010 . 